\title{
Biological links between nanoparticle biosynthesis and stress responses in bacteria
}

\section{Enlaces biológicos entre la biosíntesis de nanopartículas y las respuestas al estrés en bacterias}

Angela Chen, Benjamin K. Keitz, Lydia M. Contreras*

McKetta Department of Chemical Engineering, The University of Texas at Austin, $200 \mathrm{E}$ Dean Keeton St. Stop C0400 Austin, Texas, USA.

*Corresponding author

E-mail address: lcontrer@che.utexas.edu (L. Contreras)

Article history:

Received: 8 May 2018 / Received in revised form: 12 July 2018 / Accepted: 27 July 2018 / Published online: 1 October 2018.

https://doi.org/10.29267/mxjb.2018.3.4.44

\begin{abstract}
There is rising interest in nanoparticle biosynthesis using bacteria due to the potential for applications in bioremediation, catalysis, or as antimicrobials. However, biosynthesis remains limited by the inability to control nanoparticle morphology and size due to the lack of knowledge regarding explicit molecular mechanisms. Due to their importance in nanoparticle biosynthesis and as antimicrobials, we focus our discussion on silver, gold, and copper nanoparticles. We discuss recent efforts to elucidate reduction mechanisms that have identified generic enzymes and metal resistance genes as strong candidates to facilitate nanoparticle biosynthesis. Although it is known that these enzymes and genes play significant roles in maintaining bacterial homeostasis, there are few reports discussing this topic. Thus, we discuss examples of how metal resistance genes are conserved across bacteria and have been shown to be important for both nanoparticle biosynthesis and processes such as virulence or oxidative stress responses. Overall, this review highlights biological connections between nanoparticle biosynthesis and stress responses by examining the role of reductases and metal resistance genes in both processes. This understanding provides a greater role for nanoparticle biosynthesis in bacteria and could enable a systemsbiology level of control over nanoparticle biosynthesis.
\end{abstract}


Keywords: Metal resistance, nanoparticles, stress responses

\section{RESUMEN}

Existe un creciente interés en la biosíntesis de nanopartículas utilizando bacterias debido al potencial de aplicaciones en biorremediación, catálisis o como antimicrobianos. Sin embargo, la biosíntesis sigue siendo limitada por la incapacidad de controlar la morfología y el tamaño de las nanopartículas debido a la falta de conocimiento sobre los mecanismos moleculares explícitos. Debido a su importancia en la biosíntesis de nanopartículas y como antimicrobianos, enfocamos nuestra discusión en las nanopartículas de plata, oro y cobre. Discutimos los esfuerzos recientes para dilucidar los mecanismos de reducción que han identificado enzimas genéricas y genes de resistencia de metales como candidatos importantes para facilitar la biosíntesis de nanopartículas. Aunque se sabe que estas enzimas y genes desempeñan un papel importante en el mantenimiento de la homeostasis bacteriana, hay pocos informes que analicen este tema. Por lo tanto, discutimos ejemplos de cómo los genes de resistencia de metales se conservan a través de las bacterias y se ha demostrado que son importantes tanto para la biosíntesis de nanopartículas como para procesos tales como la virulencia o las respuestas al estrés oxidativo. En general, esta revisión destaca las conexiones biológicas entre la biosíntesis de nanopartículas y las respuestas al estrés mediante el análisis sobre papel de las reductasas y los genes de resistencia del metal en ambos procesos. Este conocimiento proporciona un papel más importante para la biosíntesis de nanopartículas en bacterias y podría permitir un nivel de biología de sistemas de control sobre la biosíntesis de nanopartículas.

Palabras clave: Nanopartículas, resistencia a metal, respuestas de estrés

\section{INTRODUCTION}

Bacteria encounter a diverse array of contaminants and toxins in their environment and have evolved numerous mechanisms to handle these stresses. As such, due to the importance of common stresses such as $\mathrm{pH}$, temperature, and oxidative/nitrosative stress in biotechnological, medical, and industrial applications, numerous reviews have been written about these conditions (Lushchak 2014; Krulwich et al. 2011; Shivaji and Prakash 2010). Many bacteria encounter strongly or mildly acidic conditions in a host or their native environments; in this context, mechanisms to handle fluctuations in proton concentrations are needed. Acid-induced stress can result in decreased enzyme activity, membrane and DNA damage, and acid-induced protein unfolding. Bacteria combat this stress by promoting proton efflux, sequestering protons through biochemical reactions, repairing and preventing damage to macromolecules, or altering permeability of the membrane (Lund et al. 2014). In addition to proton fluctuations, bacteria must also endure temperature changes in the environment that 
can result in perturbations in membrane fluidity and decrease transcription, translation, and DNA replication efficiency by altering the secondary structure stability of RNA and DNA (Jiang et al. 1997). During temperature changes, bacteria overexpress cold or heat shock proteins that act as chaperones to facilitate transcription and translation by destabilizing mRNA secondary structures, preventing protein misfolding, and assisting in protein refolding and renaturation (Jiang et al. 1997; Parsell et al. 1993). Similarly, oxidative/nitrosative stress is quite toxic to bacteria due to the various downstream effects that occur after production of reactive oxygen species (ROS) and reactive nitrogen species (RNS). These species can cause lipid peroxidation, protein damage through the formation of disulfide bonds and destruction of Fe-S clusters, and DNA mutations and damage, resulting in cell death (Storz and Imlay 1999). Thus, the response to oxidative stress has been well-studied in bacteria and typically involves activation of the OxyR, SoxS, or RpoS regulons in Escherichia coli. These regulons control expression of genes responsible for hydrogen peroxide detoxification, resistance to superoxide radicals, and general stress responses, respectively (Chiang and Schellhorn 2012). Due to the damage at the DNA or protein level of the aforementioned stresses, many bacteria have dedicated specific response mechanisms to theses stresses. In addition to the mechanisms behind these stresses, interest in bacterial exposure to metals is growing as metals can evoke similar effects to oxidative or $\mathrm{pH}$ stress.

The increasing prevalence of metals in the environment and the interest in using metals and metal nanoparticles as antimicrobials has resulted in significant efforts to understand how metal exposure affects bacteria. Essential metals such as copper, iron, and zinc are utilized as enzymatic cofactors or as components of transcriptional regulators in bacteria. Thus, known operons dedicated to maintaining homeostasis of these metals can be found in Gram-positive and Gram-negative bacteria. Similar to the response to acid or oxidative stress, bacteria upregulate efflux of the offending compounds, alter membrane permeability to prevent ion importation, sequester the metal ions, and activate repair mechanisms of macromolecules. As such, these operons typically consist of P-ATPase-like pumps, metallochaperones, and metal-responsive transcriptional regulators that are triggered at high intracellular metal concentrations to reduce metal toxicity. For rare or non-essential metals, such as silver and gold, few bacteria possess any genes or operons geared towards resistance of these metals. Therefore, they must rely upon general stress response mechanisms to detoxify these metals, which can be less effective than metal-specific responses. Table 1 lists model organisms and their operons for metal resistance. Regardless of the metal, many of these detoxification mechanisms involve altering the metal speciation to form metal nanoparticles that are less toxic than their ionic form. 
Table 1. Model organisms and their operons for metal resistance

\begin{tabular}{|c|c|c|c|}
\hline Gene(s) & Organism & Function & Reference \\
\hline silE & $\begin{array}{l}\text { Salmonella } \\
\text { typhimurium }\end{array}$ & $\begin{array}{l}\text { Periplasmic } \mathrm{Ag}(\mathrm{I}) \text {-binding } \\
\text { protein }\end{array}$ & $\begin{array}{l}\text { (Randall et al. 2015; } \\
\text { Silver 2003; Gupta et } \\
\text { al. 1999) }\end{array}$ \\
\hline silRS & $\begin{array}{l}\text { Salmonella } \\
\text { typhimurium }\end{array}$ & $\begin{array}{l}\text { Two-component } \\
\text { transcriptional regulatory } \\
\text { system }\end{array}$ & $\begin{array}{l}\text { (Randall et al. 2015; } \\
\text { Silver 2003; Gupta et } \\
\text { al. 1999) }\end{array}$ \\
\hline silP & $\begin{array}{l}\text { Salmonella } \\
\text { typhimurium }\end{array}$ & P-type ATPase transporter & $\begin{array}{l}\text { (Randall et al. 2015; } \\
\text { Silver 2003; Gupta et } \\
\text { al. 1999) }\end{array}$ \\
\hline silCBA & $\begin{array}{l}\text { Salmonella } \\
\text { typhimurium }\end{array}$ & $\begin{array}{l}\text { (RND)-type } \mathrm{Ag}(\mathrm{I}) / \mathrm{H}^{+} \\
\text {efflux transporter }\end{array}$ & $\begin{array}{l}\text { (Randall et al. 2015; } \\
\text { Silver 2003; Gupta et } \\
\text { al. 1999) }\end{array}$ \\
\hline golB & $\begin{array}{l}\text { Salmonella enterica } \\
\text { serovar Typhimurium }\end{array}$ & $\begin{array}{l}\text { Putative metal-binding } \\
\text { protein }\end{array}$ & $\begin{array}{l}\text { (Checa and Soncini } \\
\text { 2011) }\end{array}$ \\
\hline gesABC & $\begin{array}{l}\text { Salmonella enterica } \\
\text { serovar Typhimurium }\end{array}$ & CBA-efflux system & $\begin{array}{l}\text { (Checa and Soncini } \\
\text { 2011) }\end{array}$ \\
\hline golT & $\begin{array}{l}\text { Salmonella enterica } \\
\text { serovar Typhimurium }\end{array}$ & metal exporter & $\begin{array}{l}\text { (Checa and Soncini } \\
\text { 2011) }\end{array}$ \\
\hline golS & $\begin{array}{l}\text { Salmonella enterica } \\
\text { serovar Typhimurium }\end{array}$ & $\begin{array}{l}\text { Metal-responsive } \\
\text { transcriptional regulator }\end{array}$ & $\begin{array}{l}\text { (Checa and Soncini } \\
\text { 2011) }\end{array}$ \\
\hline pcoE & Escherichia coli & Copper-binding protein & $\begin{array}{l}\text { (Ramanathan et al. } \\
\text { 2013) }\end{array}$ \\
\hline cusF & Escherichia coli & Copper-binding protein & (Das et al. 2016) \\
\hline copA & Enterococcus hirae & CPX-copper type ATPase & $\begin{array}{l}\text { (Magnani and Solioz } \\
\text { 2005; Solioz and } \\
\text { Stoyanov 2003) }\end{array}$ \\
\hline copB & Enterococcus hirae & CPX-copper type ATPase & $\begin{array}{l}\text { (Magnani and Solioz } \\
\text { 2005; Solioz and } \\
\text { Stoyanov 2003) }\end{array}$ \\
\hline $\operatorname{copY}$ & Enterococcus hirae & $\begin{array}{l}\text { copper-responsive } \\
\text { repressor }\end{array}$ & $\begin{array}{l}\text { (Magnani and Solioz } \\
\text { 2005; Solioz and } \\
\text { Stoyanov 2003) }\end{array}$ \\
\hline copZ & Enterococcus hirae & copper chaperone & $\begin{array}{l}\text { (Magnani and Solioz } \\
\text { 2005; Solioz and } \\
\text { Stoyanov 2003) }\end{array}$ \\
\hline cusR & Escherichia coli & cus operon regulator & $\begin{array}{l}\text { (Das et al. 2016; } \\
\text { Rensing and Grass } \\
\text { 2003; Bondarczuk } \\
\text { and Piotrowska-Seget } \\
\text { 2013) }\end{array}$ \\
\hline cusS & Escherichia coli & cus operon sensor & $\begin{array}{l}\text { (Das et al. } 2016 \text {; } \\
\text { Rensing and Grass } \\
\text { 2003; } \quad \text { Bondarczuk }\end{array}$ \\
\hline
\end{tabular}




\begin{tabular}{|c|c|c|c|}
\hline & & & $\begin{array}{l}\text { and Piotrowska-Seget } \\
\text { 2013) }\end{array}$ \\
\hline cusCBA & Escherichia coli & $\begin{array}{l}\text { cation/proton antiporter } \\
\text { complexes for metal ion } \\
\text { exportation }\end{array}$ & $\begin{array}{l}\text { (Das et al. 2016; } \\
\text { Rensing and Grass } \\
\text { 2003; Bondarczuk } \\
\text { and Piotrowska-Seget } \\
\text { 2013) }\end{array}$ \\
\hline cusF & Escherichia coli & $\begin{array}{l}\text { Periplasmic } \\
\text { metallochaperone }\end{array}$ & $\begin{array}{l}\text { (Das et al. 2016; } \\
\text { Rensing and Grass } \\
\text { 2003; Bondarczuk } \\
\text { and Piotrowska-Seget } \\
\text { 2013) }\end{array}$ \\
\hline cueR & Escherichia coli & Transcriptional activator & $\begin{array}{l}\text { (Das et al. 2016; } \\
\text { Rensing and Grass } \\
\text { 2003; Bondarczuk } \\
\text { and Piotrowska-Seget } \\
\text { 2013) }\end{array}$ \\
\hline copA & Escherichia coli & P-type ATPase & $\begin{array}{l}\text { (Das et al. 2016; } \\
\text { Rensing and Grass } \\
\text { 2003; Bondarczuk } \\
\text { and Piotrowska-Seget } \\
\text { 2013) }\end{array}$ \\
\hline cueO & Escherichia coli & Copper oxidase & $\begin{array}{l}\text { (Das et al. 2016; } \\
\text { Rensing and Grass } \\
\text { 2003; Bondarczuk } \\
\text { and Piotrowska-Seget } \\
\text { 2013) }\end{array}$ \\
\hline
\end{tabular}

It is widely believed that nanoparticle biosynthesis is a stress response mechanism used to reduce the toxicity of metal ions by changing their speciation and limiting transport into the cell (Gadd 2010). Thus, metal exposure likely activates the organism's native metal toxicity or general stress response pathways and nanoparticle biosynthesis is just a byproduct of these detoxification processes. However, there are several instances in which bacteria interact with metals to form functional metal or metal oxide nanoparticles. The most prominent example of this is magnetotactic bacteria, particularly Magnetospirillum species. First described in 1975, Magnetospirillum can orient itself in magnetic fields using biologically-synthesized magnetite that is stored within vesicles (Blakemore 1975). This phenomenon has been traced back to specific genetic pathways and operons in Magnetospirillum that are well-characterized in regards to their role in controlling nanoparticle formation, morphology, and size (Lohße et al. 2014). Although these bacteria are a unique exception, as the majority of bacteria do not form functional nanoparticles, examples like them have resulted in increased interest in linking biosynthesis to biological functions. Furthermore, metallic nanoparticles have diverse uses for bioremediation, drug 
delivery, and antimicrobials due to their advantageous optical and photochemical properties (Pankhurst et al. 2003; Schröfel et al. 2014). This has led to numerous reports of nanoparticle biosynthesis in organisms ranging from bacteria to fungi and plants for a variety of metals (silver, gold, palladium, metal oxides, etc.) (De Windt et al. 2005; Riddin et al. 2006; Huang et al. 2007). Since nanoparticle morphology and size strongly dictates application, the effect of conditions such as $\mathrm{pH}$, temperature, reaction time, and metal concentration on nanoparticle properties has also been investigated, as summarized in numerous reviews (Mittal et al. 2013; Iravani et al. 2014; Hulkoti and Taranath 2014). However, nanoparticle biosynthesis remains limited by an inability to finely control nanoparticle size and morphology due to a lack of knowledge regarding explicit molecular mechanisms for nanoparticle biosynthesis. Recent endeavors have brought us closer to understanding how metal reduction and nanoparticle formation occur in microorganisms. For instance, common enzymes have been identified such as various reductases. A general milieu of reducing factors such as amino acids or peptides present in the cytoplasm have also been identified as facilitators of nanoparticle biosynthesis (Durán et al. 2015; Prasad et al. 2016; Prakash et al. 2013). Conversely, reduction of heavy metals such as $\mathrm{Hg}(\mathrm{II}), \mathrm{Cr}(\mathrm{VI})$, and $\mathrm{As}(\mathrm{V})$ to their less toxic forms $\mathrm{Hg}(\mathrm{II}) / \mathrm{Hg}^{0}, \mathrm{Cr}(\mathrm{III})$, and $\mathrm{As}(\mathrm{III})$, respectively in bacteria has been shown to be facilitated by metal-specific genes such as the mer operon, metalloregulatory protein ArsR, and chromate reductase ChrR that are found in metal resistance pathways (Dixit et al. 2015). Despite these efforts, it is still unknown how much of nanoparticle biosynthesis is biologically controlled by genetic pathways as opposed to being a result of reduction chemistry.

The majority of nanoparticle biosynthetic studies have focused only on inhibition or expression of a single protein, neglecting the role of metabolic or regulatory pathways. This is despite already existing evidence in Shewanella and Magnetosprillum of wellcharacterized metal reduction pathways (Mtr pathway, mamAB operon). These challenges have been echoed by several reviews that summarize the current state of the literature in bacterial nanoparticle biosynthesis and highlight specific metals or certain classes of reducing factors (enzymes, small molecules, or peptides). Aside from nanoparticle biosynthesis, many of these factors also possess roles in maintaining general bacterial homeostasis, but this is rarely discussed. In this review we will provide examples of the current state of knowledge regarding enzymatic biosynthesis of silver, gold, and copper nanoparticles. We also highlight how this field could be improved by examining the role of these enzymes in other pathways that can intersect with nanoparticle biosynthesis as seen in Figure 1. Although these enzymes naturally participate in numerous metabolic pathways, we will focus our discussion to those pertaining to oxidative stress/acid responses, pathogenicity, and the biosynthesis of essential metabolites. The aforementioned metals were selected for discussion due to their relevance to nanoparticle biosynthesis and antimicrobials. Finally, we will discuss how genes in metal resistance operons in bacteria can play critical roles in biosynthesis and in general stress responses, suggesting an interesting connection between metal reduction, stress responses, and nanoparticle biosynthesis. 


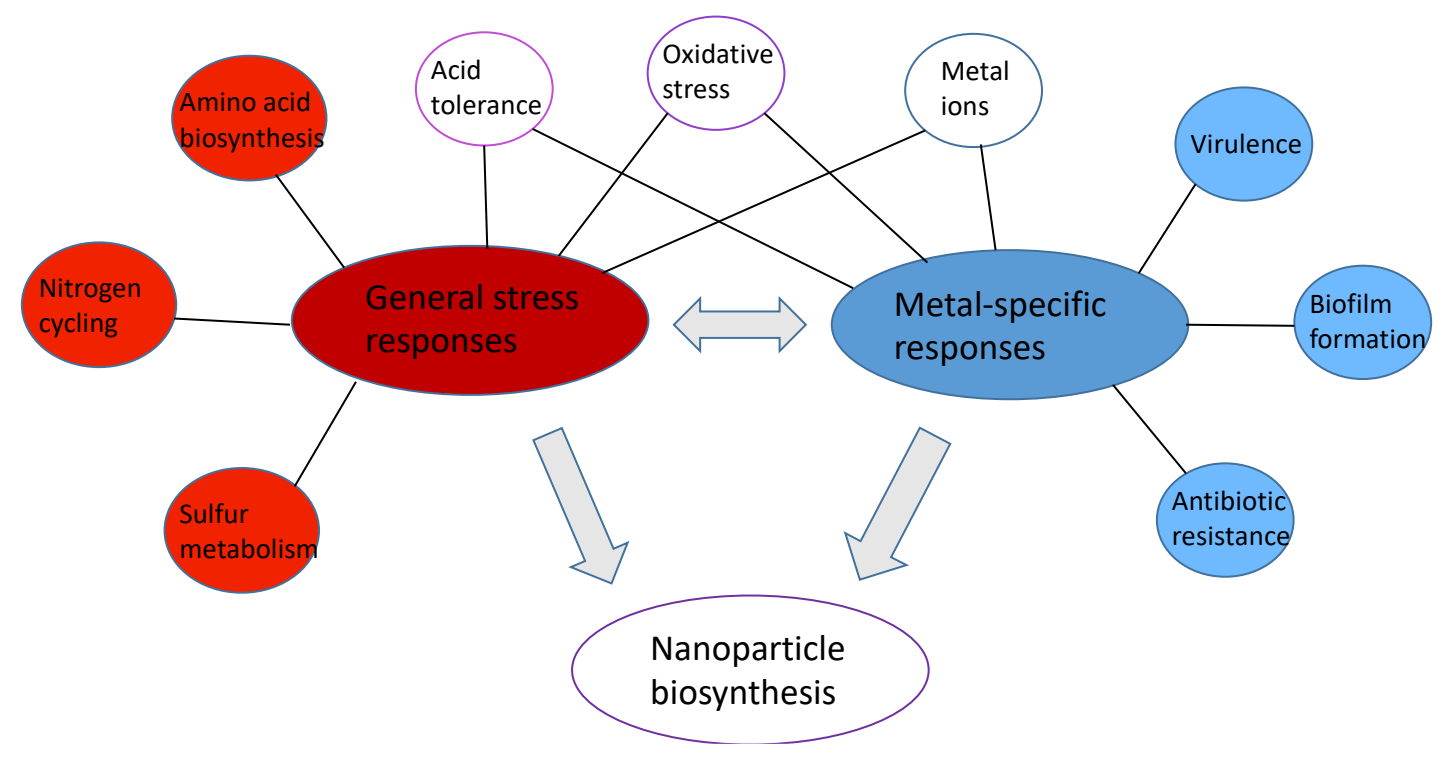

Fig. 1. Diagram of how nanoparticle biosynthesis could be connected to numerous metabolic processes. General and metal-specific stress responses are known to be involved in nanoparticle biosynthesis, but also play essential roles in processes such as sulfur metabolism and antibiotic resistance.

\section{Silver}

Silver is one of the most toxic metals for bacteria, and it is believed that silver nanoparticles exert toxicity by penetrating the cell membrane, creating free radicals and ROS, and by releasing silver ions that can bind to key enzymes or intercalate within DNA, causing cell death (Prabhu and Poulose 2012). This toxicity makes silver a promising antimicrobial candidate so silver nanoparticle biosynthesis is very well-studied compared to other metals. As such, numerous studies have been published that describe extra- and intracellular biosynthesis of functional silver nanoparticles (AgNPs) of various sizes and shape using fungi, plants, and bacteria; these nanoparticles are typically characterized using transmission electron microscopy (TEM) or scanning electron microscopy (SEM) (Iravani et al. 2014; Hulkoti and Taranath 2014; Fayaz et al. 2010). These particles commonly possess antimicrobial activity as demonstrated by testing the synthesized AgNPs against medicallyrelevant bacteria such as Salmonella, Pseuodomonas, E. coli, and Bacillus. Frequently, these microbially synthesized AgNPs exhibit equivalent or greater antimicrobial activity than chemically synthesized nanoparticles. Thus, the potent antimicrobial activity of AgNPs has led to significant progress in understanding AgNP biosynthesis from an enzymatic standpoint.

Specifically, nitrate reductase, a reductase in prokaryotes that contains a molybdenum cofactor and facilitates the conversion of nitrate to nitrite (Figure 2), has emerged as a strong candidate that enables AgNP biosynthesis in fungi and bacteria. 
There are three types of nitrate reductases that exist in bacteria; respiratory nitrate reductases

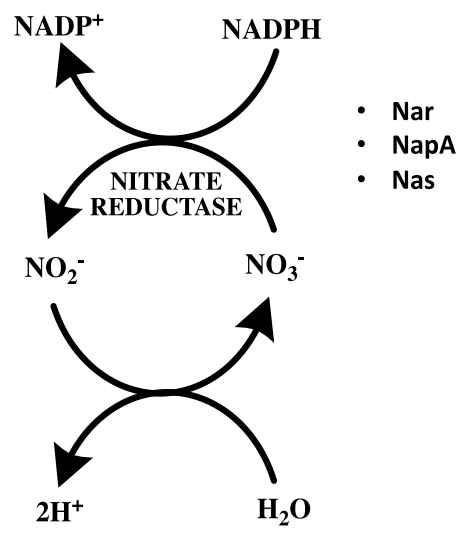

Fig. 2. Schematic of the general nitrate reductase reaction.
(Nar), periplasmic nitrate reductase (NapA), and an assimilatory nitrate reductase (Nas) (González et al. 2006). Examples of the role of nitrate reductase in AgNP biosynthesis have been demonstrated in vivo and in vitro. In vitro studies using purified nitrate reductase from Fusarium oxysporum treated with hydroxyquinoline (an electron shuttle), $1 \mathrm{mM} \mathrm{AgNO}$, phytochelatin (capping agent), and NADH/NADPH were capable of catalyzing AgNP synthesis at $25^{\circ} \mathrm{C}$. This was confirmed spectroscopically by the presence of an absorbance peak at $413 \mathrm{~nm}$, which indicates AgNP formation. Furthermore, sequential removal of each component resulted in elimination of the 413 $\mathrm{nm}$ peak, demonstrating the significance of each factor in AgNP biosynthesis (Kumar et al. 2007). Comparative studies of AgNP biosynthesis using supernatant from Enterobacteriacae that was treated with piperitone, a known inhibitor of nitrate reductase, showed an approximately 50\% decrease in absorbance at $430 \mathrm{~nm}$ (indicative of $\mathrm{AgNP}$ formation) when pipertone was present, supporting the role of nitrate reductase in AgNP biosynthesis (Shahverdi et al. 2007). Other studies in E. coli also support nitrate reductase as a key factor in biosynthesis. Experiments using E. coli supernatant found that nitrate-rich media (a known inducer of nitrate reductase) nearly tripled the absorbance at $420 \mathrm{~nm}$ from 0.42 in nitrate-poor media to 1.23, indicating increased AgNP production. The reduction was also temperature-sensitive up to $60^{\circ} \mathrm{C}$, supporting a nitrate reductasemediated process (Gurunathan et al. 2009). A silver resistant strain of E. coli that maintains normal growth in the presence of $\mathrm{mM}$ concentrations of $\mathrm{Ag}$ was found to produce periplasmic AgNPs after silver exposure. Using Shewanella oneidensis as a guide, deletions of the c-type chromosome subunits of reductases such as NapB, NapC, NarI, and NarV were created

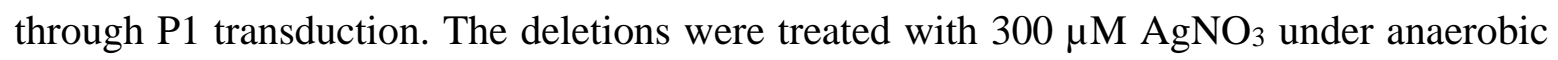
conditions and only the NapC deletion showed inhibition of AgNP biosynthesis, as evidenced by a lack of color change. This effect was confirmed by complementation studies using a lac promoter-driven NapC expression plasmid that provided partial recovery of biosynthetic activity (Lin et al. 2014). These results corroborate findings from previous studies demonstrating the role of nitrate reductases in AgNPs. However, it is interesting to note that in all of these cases, complete inhibition of biosynthesis was not observed. This suggests that nitrate reductases account for only a portion of the AgNP biosynthetic mechanism in bacteria.

Nitrate reductases are also essential components of bacterial metabolism as a means of nitrate respiration and denitrification. In particular, nitrate reductase is key for anaerobic growth conditions where bacteria may have to rely upon respiration using nitrate/nitrogen rather than oxygen (González et al. 2006). This is especially relevant for pathogenic bacteria 
that must cope with stresses induced by host defense mechanisms. For instance, studies of a knockout of narGHJI in Mycobacterium tuberculosis under hypoxic conditions and acid stress found that deletion of NarGHJI results in increased sensitivity to acid-induced killing. Thus, nitrate reductase in $M$. tuberculosis promotes virulence and survival by facilitating anaerobic respiration and providing acid resistance (Tan et al. 2010). Nitrate reductases have also been shown to be capable of nitric oxide detoxification in some bacteria. E. coli knockouts of NsfA, the periplasmic cytochrome c nitrate reductase, showed no reduction of $\mathrm{NO}^{\circ}$ as measured by a Clarke-type electrode in anaerobic conditions, demonstrating the role of NsfA in $\mathrm{NO}^{\circ}$ reduction (Poock et al. 2002). This is in stark contrast to the parent strain that reduced $\mathrm{NO}^{\circ}$ at rates comparable to oxygen, nitrate, and nitrite. Assessment of the growth of $E$. coli under $\mathrm{NO}^{\circ}$ also supports the role of $\mathrm{NsfA}^{-} \mathrm{NO}^{\circ}$ detoxification with $\mathrm{NsfA}^{-}$strains showing complete growth inhibition at $150 \mu \mathrm{mol} / \mathrm{mL} \mathrm{NO}{ }^{*}$ while there was no effect on the parent strain (Poock et al. 2002). These nitrate reductases are therefore essential for oxidative stress responses due to reactive nitrogen species. These examples highlight the connection between nanoparticle biosynthesis, the role of nitrate reductases, and a general stress response. In the case of denitrification, dissimilatory nitrate reduction has also been correlated to biomineralization in Magnetospirillum. Deletion of the nap gene (periplasmic nitrate reductase) resulted in impaired biomineralization and overexpression of denitrification genes (nir, nos, and nor) resulted in increased magnetite biosynthesis (Li and Pan 2012). In this case the response to RNS and denitrification can offer insight into the higher-level pathways that are affected during nanoparticle biosynthesis.

Aside from general stress responses, there have been reports of metal-specific resistance machinery facilitating AgNP biosynthesis. Silver is a non-essential metal so few species possess silver specific homeostasis machinery similar to what is observed for copper, zinc, or iron. However, there are examples of promiscuous metal resistance and plasmidencoded resistance. Salmonella typhimurium was the first organism in which exogenous resistance was observed with a plasmid (pMG101) encoding nine ORFs that have collectively been termed the sil operon, listed in Table 1 (Gupta et al. 1999). Of the nine ORFs, only the function of silE has been determined. Using nano-Electrospray Ionization-Mass Spectrometry (nano-ESI-MS), it was found that SilE acts as a molecular sponge that can bind up to $8 \mathrm{Ag}^{+}$ions, $6 \mathrm{Cu}^{+}$ions, $5 \mathrm{Zn}^{2+}$ ions, or $2 \mathrm{Ni}^{2+}$ ions, enabling it to act as a first line of defense in response to silver stress (Asiani et al. 2016). This ability of SilE to bind silver ions could be what facilitates its role in AgNP biosynthesis in silver-resistant bacteria. Silverresistant Morganella sp. was found to survive concentrations greater than $0.5 \mathrm{mM} \mathrm{Ag}$ and possessed genes with $99 \%$ similarity to the reported sequence for silE, which has homology to copper resistance genes. Treatment of the culture supernatant with $5 \mathrm{mM} \mathrm{AgNO} 3$ resulted in formation of AgNPs with a size of $20 \pm 5 \mathrm{~nm}$, supporting the role of a specialized metal stress response in nanoparticle biosynthesis (Parikh et al. 2008; Parikh et al. 2011). The importance of sil genes for silver resistance has also been demonstrated in clinical bacteria isolated from a trauma center. Over $50 \%$ of isolates that were able to grow in $250 \mathrm{uM} \mathrm{Ag}^{+}$ 
contained sil genes. Suggesting a potential connection between metal resistance and nanoparticle biosynthesis, two isolates that contained sil genes and had minimum inhibitory concentration (MIC) values of $5.5 \mathrm{mM}$ were also able to produce intracellular AgNPs as confirmed by SEM (Finley et al. 2015). In addition to silver resistance, members of the sil operon have been shown to be important for additional functions. Investigation of the bacterial pathogen, Francisella tularensis, using genetic knockouts and complementation strains of silC, a silver cation efflux protein, found that silC was essential for protection against antibiotics, oxidative stress, and macrophages and also promotes virulence in mice (Alqahtani et al. 2018). Some bacteria have evolved the ability to utilize existing metal resistance machinery aside from the sil operon to facilitate silver detoxification. For example, homologues of silCFBA, termed cusCFBA, have been identified in E. coli. Proteomic studies of silver-resistant $E$. coli identified CusF and CusB as constitutively expressed and a $\Delta c u s F$ strain exhibited a loss of silver resistance, demonstrating that the Cus system is utilized for both copper and silver toxicity in E. coli (Lok et al. 2008). Corroborating these results, studies of $E$. coli under copper stress found that CusS can also bind $\mathrm{Ag}(\mathrm{I})$ in addition to $\mathrm{Cu}(\mathrm{I})$ (Gudipaty and McEvoy 2014). As seen in Figure 3, there are connections between nanoparticle biosynthesis and general stress responses through metal resistance genes that are present in both phenomena. Highlighting this, several bacteria that have demonstrated biosynthetic capability also possess metal resistance genes involved in virulence or antibiotic resistance.
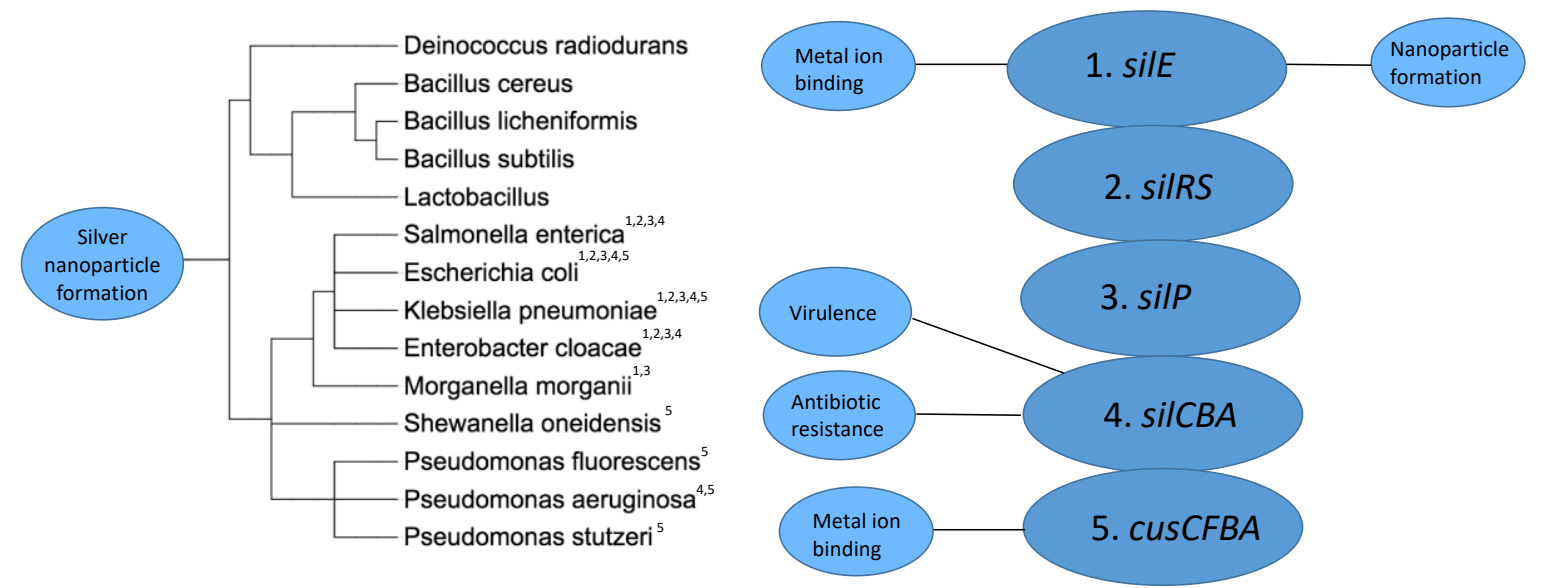

Fig. 3. Phylogenetic tree of some of the bacteria known to produce silver nanoparticles with numbers denoting the presence of specific silver resistance genes. Many of these genes also play roles in the general stress responses to antibiotics or metal ions. 


\section{Gold}

Gold is a nonessential metal, but gold nanoparticles possess several beneficial properties ideal for medical imaging, drug delivery, catalysis, and as an antimicrobial (Daniel and Astruc 2004; Ghosh et al. 2008; Mubarakali et al. 2011). Studies on the enzymatic biosynthesis of gold nanoparticles (AuNPs) have revealed some promising and familiar candidates. Nitrate reductase, which has been strongly implicated in AgNP biosynthesis, has also been found to play a part in AuNP biosynthesis. The supernatant of Pseudomonas denitrificans was treated with $100 \mathrm{ppm}$ of $\mathrm{HAuCl}_{4}$ at $37^{\circ} \mathrm{C}$ and $\mathrm{pH}$ of 3 , resulting in the formation of spherical AuNPs. The activity of nitrate reductase towards its natural substrate, nitrate, was assessed before and after AuNP biosynthesis and decreased from 0.87 $\mathrm{uM} / \mathrm{min} / \mathrm{mL}$ to $0.1015 \mathrm{uM} / \mathrm{min} / \mathrm{mL}$ after biosynthesis, suggesting involvement of nitrate reductase in AuNP biosynthesis (Mewada et al. 2012). Studies from nitrogen-fixing cyanobacteria Anabeana sp., Nostoc, and Azotobacter species also support an interplay between AuNP biosynthesis and nitrogen-cycling enzymes. Treatment of these bacterial cultures with 0.25-0.5 mM HAuCl 4 resulted in AuNPs with sizes ranging from 10-30 nm. Upon addition of nitrogen to the culture media, a condition that eliminates nitrogen fixing, AuNP biosynthesis by these bacteria was abolished. Species incapable of nitrogen fixing were also shown to be unable to synthesize AuNPs. Furthermore, nitrogen fixing in these bacteria is facilitated by the enzyme nitrogenase, which resides within specialized cells known as heterocysts; importantly AuNPs were also found to be localized in this area. These results strongly support the role of a nitrogenase and a connection between nitrogen fixing and AuNP biosynthesis (Brayner et al. 2007; Radtsig et al. 2016).

In addition to nitrate reductases or nitrogenases, some efforts have highlighted the role of NADPH-sulfite reductase in mediating AuNP formation. Supernatant from B. subtilus containing disulfide reductase and keratinase was treated with $\mathrm{HAuCl}_{4}$ to create spherical AuNPs with sizes ranging from 50-80 nm. Oxidation of the reductase and reduction of auric ions was believed to occurr simultaneously (Gupta et al. 2015). NADPH-sulfite reductase was purified from the supernatant of Thermomonospora sp. using fast protein liquid chromatography (FPLC) and assayed for sulfite reductase activity. The pure sulfite reductase was then treated with $\mathrm{HAuCl}_{4}, \mathrm{NADPH}, \mathrm{Na}_{2} \mathrm{SO}_{3}$, and a capping protein at $50^{\circ} \mathrm{C}$ for $4 \mathrm{hrs}$. AuNP synthesis was confirmed by a rapid color change and the appearance of an absorbance peak at $533 \mathrm{~nm}$ using UV/vis spectroscopy (Khan and Ahmad 2014). These results are corroborated by studies using the purified $E$. coli sulfite reductase that was also shown to facilitate AuNP biosynthesis, supporting the role of sulfite reductase in biosynthesis across several bacterial species (Gholami-Shabani et al. 2015). Another reductase of note is glutathione reductase (GR) in the flavoprotein disulfide reductase (FDR) family, the same family that contains MerA, a mercuric reductase central to mercury detoxification. GR was purified from $E$. coli and treated with $\mathrm{NADPH}$ and $\mathrm{HAuCl}_{4}$ to produce AuNPs through electron transfer from NADPH to enzyme-bound FAD and finally deposition onto $\mathrm{Au}^{3+}$ in 
the glutathione reductase active site. This was confirmed using MALDI-TOF and atomic absorption experiments to follow formation of GR-AuNP complexes and through GR activity assays that showed a $>90 \%$ reduction in activity towards the native substrate, glutathione, if $\mathrm{AuCl}_{4}^{-}$was also present (Scott et al. 2008). The exact mechanism of AuNP formation remains unknown in many bacteria with a few reductases appearing as potentially key components for biosynthesis. These reductases play critical roles in metabolic and stress response pathways though, further supporting the link between nanoparticle biosynthesis and general response mechanisms, particularly for non-essential metals like silver and gold.

Like nitrate reductase, sulfite reductase and glutathione reductase also function to maintain bacterial homeostasis and growth outside of nanoparticle biosynthesis. Critical to the biogeochemical sulfur cycle, sulfite reductase catalyzes the reduction of sulfite to sulfide (Figure 4) during anaerobic respiration with substrates such as sulfates, sulfites, and organosulfonates as terminal electron acceptors ( $\mathrm{Mu}$ et al. 2015). Sulfite reductase also plays a role in cysteine biosynthesis and its two subunits are encoded within the cysteine regulon (cysJIH operon) (Sekowska et al. 2000). Studies in E. coli investigating the effect of olenaolic (OA) and ursolic acids (UA), which are known to be potent inhibitors of pathogenic bacteria, utilized transcriptional fusions with a

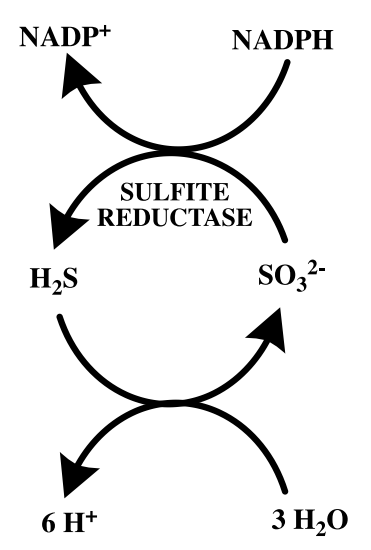

Fig. 4. Schematic of the general sulfite reductase reaction. lacZ reporter that measures $B$-galactosidase to assess the effect of OA and UA on the expression of genes involved in stress response and sulfur metabolism. Using these assays, it was determined that expression of cysJIH decreased by $82 \%$ and $83 \%$ upon treatment with OA or UA, revealing that these genes are significantly targeted by these inhibitors as compared to genes encoding for the sulfate/thiosulfate transport system (decreases of $77 \%$ and 48\%) (Grudniak et al. 2011). It is worth noting that other studies have also commented on the importance of sulfur metabolism for virulence and pathogenicity (Bogdan et al. 2001; Farmer and Thomas 2004). Furthermore, the activity of cysJIH::lacZ was shown to decrease $43 \%$ and $23 \%$ respectively in $\Delta d n a J$ and $\Delta d n a K d n a J$ strains, suggesting a potential link between sulfite reductase and stress response proteins such as the stress chaperone, DnaK (Karpinski et al. 2002). Sulfur metabolism has also been linked to metal resistance as shotgun metagenomics of a metal-contaminated marine sediment found over-representation of genes involved in dissimilatory sulfur reduction (Plewniak et al. 2013). A link between oxidative stress and nanoparticle biosynthesis is also shown through glutathione reductase (GR), which naturally functions to reduce glutathione disulfide (GSSG) to glutathione (GSH) using NADPH (Figure 5). GR is encoded for by the OxyR regulon, which responds to $\mathrm{H}_{2} \mathrm{O}_{2}$ and is one of the major components of the bacterial oxidative stress response (Zeller and Klug 2006). GSH is essential to the oxidative stress response mechanisms as it reduces disulfide 
bonds and is an electron donor for the antioxidant, glutathione peroxidase (Carmel-Harel and Storz 2000). Thus, GR is important for maintaining the functional pool of GSH present during oxidative stress. Since metals can also cause oxidative stress, it is not surprising that GR, along with other components of the oxidative stress response mechanism, is active during metal exposure and could facilitate metal ion reduction. This phenomenon is conserved across metals as GR isolated from Pseudomonas sp. strain BNF22 was recombinantly expressed in $E$. coli and shown to be capable of tellurium nanostructure (TeNS) biosynthesis after addition of $1 \mathrm{mM}$ of potassium telluride and NADPH (Pugin et al. 2014).

It has been hinted that metal resistance mechanisms may also play a role in gold reduction. For instance, metal-resistant Streptomyces griseus from a copper mine could synthesize spherical $50 \mathrm{~nm}$ AuNPs after addition of $\mathrm{HAuCl}_{4}$ (Derakhshan et al. 2012). Metal resistance mechanisms in Cupriavidus metallidurans have also been investigated. Using Xray analyses and microarray data, Reith et al. found that $C$. metallidurans utilizes a reductive precipitation mechanism in which $\mathrm{Au}(\mathrm{I})-\mathrm{S}$ complexes are reduced to $\mathrm{Au}^{0}$ or $\mathrm{Au}(\mathrm{I})-\mathrm{C}$ in a process mediated by members of the cop and mer loci. Genes such as cupR, an ortholog of cueR and golS, copA, copI, and copJ and an Au-specific operon were all found to be strongly upregulated after exposure to $\mathrm{Au}^{3+}$, suggesting a metal-specific response in this detoxification mechanism. Interestingly, ohr, katA, oxyR, and $\operatorname{sodB}$, which are genes involved in oxidative stress responses to $\mathrm{H}_{2} \mathrm{O}_{2}$ and superoxide

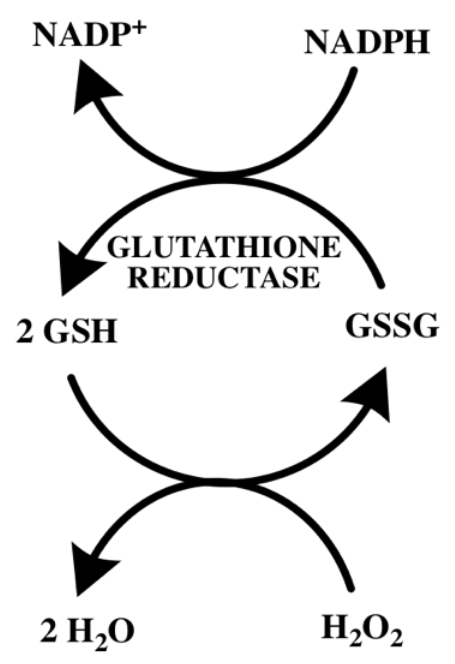

Fig. 5. Schematic of the glutathione reductase reaction. radicals, were also upregulated under $\mathrm{Au}^{3+}$ exposure, supporting crosstalk between metal stress and oxidative stress responses (Reith et al. 2009). Proteomic analysis of C. metallidurans to $\mathrm{Au}(\mathrm{III})$ has confirmed the role of a dual-metal resistance mechanism for copper and gold toxicity with CupR acting as an $\mathrm{Au}$-sensing regulator and $\mathrm{CupC}$ as an $\mathrm{Au}$ binder that facilitates detoxification through multi-metal efflux proteins (Zammit et al. 2016). This is corroborated by studies showing synergistic copper-gold detoxification in C. metallidurans where expression of the cop operon is necessary for $\mathrm{Au}$ resistance and CopA functions as an $\mathrm{Au}(\mathrm{I})$-oxidase to promote formation of $\mathrm{Au}^{0}$ nanoparticles from Au(III) (Wiesemann et al. 2018). A cellenvelope stress-responding system in Salmonella, $\mathrm{CpxR} / \mathrm{CpxA}$, has also been shown to upregulate transcription of gesABC, a CBA efflux system, in the presence of $\mathrm{Au}$ ions. This relationship was confirmed by $\operatorname{cpx} R A$ knockouts that demonstrated heightened gold sensitivity compared to the wild-type after Au exposure. These results support interaction between metal resistance and general stress response systems in bacteria (Cerminati et al. 2017). In E. coli, it has been shown that CueR, the transcriptional regulator of the cue operon that activates the promoter of CopA, is triggered by gold salts 
through cysteine residues that can recognize gold, silver, and copper. Creation of a $c u e R$ knockout eliminated induction of copA by gold (Stoyanov and Brown 2003). These current advances have illuminated how bacteria can utilize gold-specific resistance mechanisms or hijack existing machinery such as $\operatorname{cop} A$, to respond to gold toxicity as well as to silver or copper. Similar to silver, connections in bacteria between nanoparticle biosynthesis and metabolic processes can be made through the presence of metal resistance machinery (Figure 6). The literature in this area is limited though as few studies have investigated the specific effects of gold exposure on bacteria.
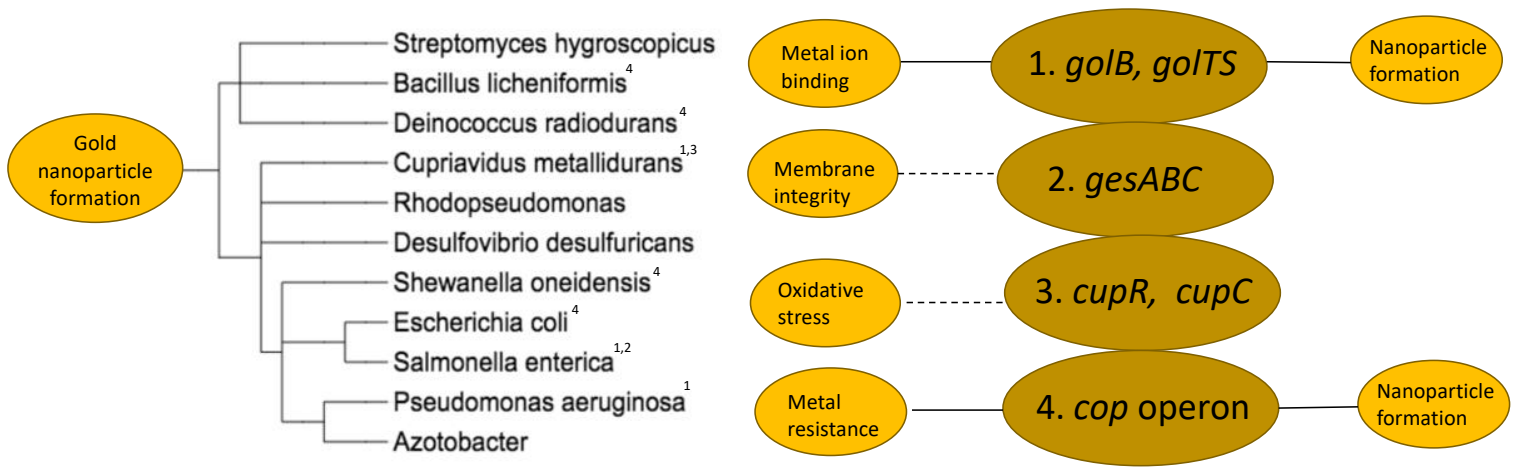

Fig. 6. Phylogenetic tree of some of the bacteria known to produce gold nanoparticles with numbers denoting the presence of specific gold resistance genes. Many of these genes also play roles in general stress responses to oxidative stress or metal ions.

\section{Copper}

Copper is an essential trace element and can be found in transcriptional regulators, storage proteins, or as a cofactor for metalloproteins and other enzymes. It is toxic at high concentrations as copper can participate in Fenton-type reactions to generate ROS or displace other metals in metalloproteins, disrupting their structure and function (Grass et al. 2011; Samanovic et al. 2012; Festa and Thiele 2012; Porcheron et al. 2013). These properties have given copper value as a potent antimicrobial and significant literature exists on copper homeostasis in bacteria. However, overuse of this metal as an antimicrobial and agricultural supplement has resulted in environmental contamination and increasing instances of the emergence of heavy metal-linked co-resistance to antibiotics (Yazdankhah et al. 2014; Li et al. 2017; Knapp et al. 2011). In addition to the ionic form, copper and copper oxide nanoparticles also possess high antimicrobial activity and have beneficial applications in optics, electronics, and catalysis. As such, there is an increasing number of reviews discussing extracellular and intracellular production of copper/copper oxide nanoparticles by Lactobacillus sp., Pseudomonas stutzeri, Morganella sp., Streptomyces, E. coli, and etc. with antimicrobial properties and sizes ranging from 8-150 nm (Rubilar et al. 2013; Durán and 
Seabra 2012). Unlike silver and gold nanoparticle biosynthesis, where bacteria typically rely upon enzymes involved in general stress responses, studies on copper biosynthesis have highlighted the role of native copper resistance operons used to maintain homeostasis.

Ramanathan et al. investigated whether silver-resistant Morganella morganii strain RP42 could produce copper nanoparticles (CuNPs) after addition of $\mathrm{CuSO}_{4}$. Through linear sweep voltammetry (LSV) and BLAST analyses, they found that Morganella could produce pure metallic copper nanoparticles through a process mediated by proteins of the sil gene cluster, which is involved in silver reduction/resistance. It is known that the periplasmic silver-binding protein (SilE) is homologous to the copper-binding proteins PcoE and CusF found in E. coli, supporting the potential for copper binding by SilE (Ramanathan et al. 2013). A copper-resistant Bacillus cereus strain that was isolated and used to produce extracellular CuNPs possessed resistance to copper concentrations greater than $10 \mathrm{mM}$ and contained several copper resistance genes such as $\operatorname{cop} A, \operatorname{cop} C, \operatorname{copD}$, and $\operatorname{cutC}$ as identified using UniProtKB (Tiwari et al. 2016). It has been shown that bacterial isolates with resistance to copper in the 3.1-4.7 $\mathrm{mM}$ range all exhibited increased expression of copA. Thus, it is highly likely that copper-resistant $B$. cereus overexpresses copA as well and that CopA may be responsible for CuNP biosynthesis (Altimira et al. 2012). These genes are conserved members of copper resistance operons and are found in many bacteria due to copper's toxicity. Examples of these operons include the cop operon found in Enterococcus hirae, the cus locus and cue system in E. coli, the copper transport operon in Streptococcus, a copper regulatory system in Bacillus, and the copRSCD operon in P. fluorescens, among others as shown in Table 1 (Das et al. 2016). In addition to copper resistance, genes in these operons have been found to play roles in oxidative stress response and virulence in Gram-positive bacteria. Transcriptional profiling and real-time quantitative PCR were used to identify a copper-responsive gene cluster in Deinococcus radiodurans that encodes for CopA, CopZ, and CsoR and shares homology with systems found in B. subtilis and M. tuberculosis. Deletion mutants of CopA demonstrated that CopA contributes to oxidative resistance from $\mathrm{H}_{2} \mathrm{O}_{2}$ exposure as a lack of copA results in decreased survival (Zhao et al. 2014). However, the exact mechanism of oxidative stress resistance in Deinococcus radidurans remains unknown. A homolog of the cop operon has also been identified in Streptococcus and contains a copper-dependent repressor (CopY), ATPase (CopA), and a copper chelator (CupA). Disruption mutants of copY, сорA, and сupA were generated through insertion of the erythromycin resistance gene and were shown to be 10-fold more sensitive to copper stress compared to the wild-type. Additionally, mice infected with $\triangle$ copA mutants had significantly lower bacterial titers and higher survival rates compared to those infected with the wild-type bacteria, supporting the role of CopA in S. pneumoniae virulence (Johnson et al. 2015). Additionally, experiments with a $\triangle$ copYAZ mutant constructed in Streptococcus mutans found that biofilm formation was greatly inhibited in the mutant strain compared to the wild-type strain, with a greater than $50 \%$ decrease in biomass in the mutant strain after exposure to $500 \mu \mathrm{M} \mathrm{CuSO}_{4}$. The copYAZ operon is also important for acid tolerance as the 
mutant strain had significantly decreased survival at $\mathrm{pH} 3.5$ compared to the wild-type (Singh et al. 2015).

In $E$. coli, copper homeostasis is maintained through two copper-responsive regulatory systems, the $\mathrm{Cu}$-sensing (cus) and the $\mathrm{Cu}$ efflux (cue) systems. One component of the cus system is CusF, a periplasmic metallochaperone that binds copper through methionine. This binding ability has been demonstrated in protein purification using CusF as an affinity tag with columns charged with copper (Cantu-Bustos et al. 2016). Numerous studies examining the response of $E$. coli to copper ion stress have revealed additional roles for copper resistance in the areas of oxidative stress, amino acid deprivation, and osmotic stress. Using real-time PCR, expression levels of cusCFBA, copA, cusS, and cusR were found to be upregulated 2-7-fold under osmotic stress and promoted increased osmotolerance in $E$. coli (Xiao et al. 2017). In conditions mimicking host environments where anaerobic amino acid limitation occurs, expression of $c u s C F B A$ was upregulated and cells lacking cusCFBA and copA suffered from severe growth defects and reduced ATP production (Ka et al. 2013). Additionally, a knockout of $\operatorname{cop} A$ inhibited Glu biosynthesis through glutamate synthase and resulted in increased acid sensitivity (Djoko et al. 2017). This is interesting as several amino acids have been suggested as reducing agents for nanoparticle biosynthesis, so there may be a connection between biosynthesis, metal-specific responses, and basic metabolism. This possibility is further supported by the fact that sulfite reductase, which is key for cysteine biogenesis, has also been implicated in nanoparticle biosynthesis. Microarray studies in $E$. coli investigating sub-lethal and excess copper concentrations found upregulation of genes in the cus and cue operons in addition to regulons corresponding to superoxide stress response and iron homeostasis. This observation supports overlap between copper resistance and other stress response mechanisms (Kershaw et al. 2005). Aside from ionic copper exposure, genes found in the copper resistance operons are also essential for responding to the oxidative stress induced by nanoparticle exposure. Using real-time PCR, expression levels of copA, сиеO, and cusC peaked up to 13-, 6-, and 4.8-fold compared to controls after 60 mins of exposure to copper oxide nanoparticles (CuO NPs) in E. coli (Moore et al. 2017). Exposure of Pseudomonas aerginosa to $\mathrm{CuO}$ NPs resulted in upregulation of genes involved in copper resistance including $\operatorname{cop} R, c z c R$, and $i r l R$ under concentrations from 1-50 mg/L. Genes encoding enzymes in the copper resistance protein precursor (pcoAB) also experienced 130-634.3 fold increases in expression under $\mathrm{CuO} \mathrm{NP}$ exposure (Guo et al. 2017). These results demonstrate how copper resistance machinery is upregulated during nanoparticle biosynthesis as well as in response to nanoparticles themselves to potentially protect against oxidative stress and membrane damage. As one of the most well-studied metals with regards to bacterial resistance, it is interesting to note how much overlap exists between genes involved in copper resistance and nanoparticle biosynthesis and those upregulated under a variety of environmental stress conditions (Figure 7). Further supporting this observation, many bacteria that have demonstrated the ability to produce CuNPs also possess copper resistance genes. 


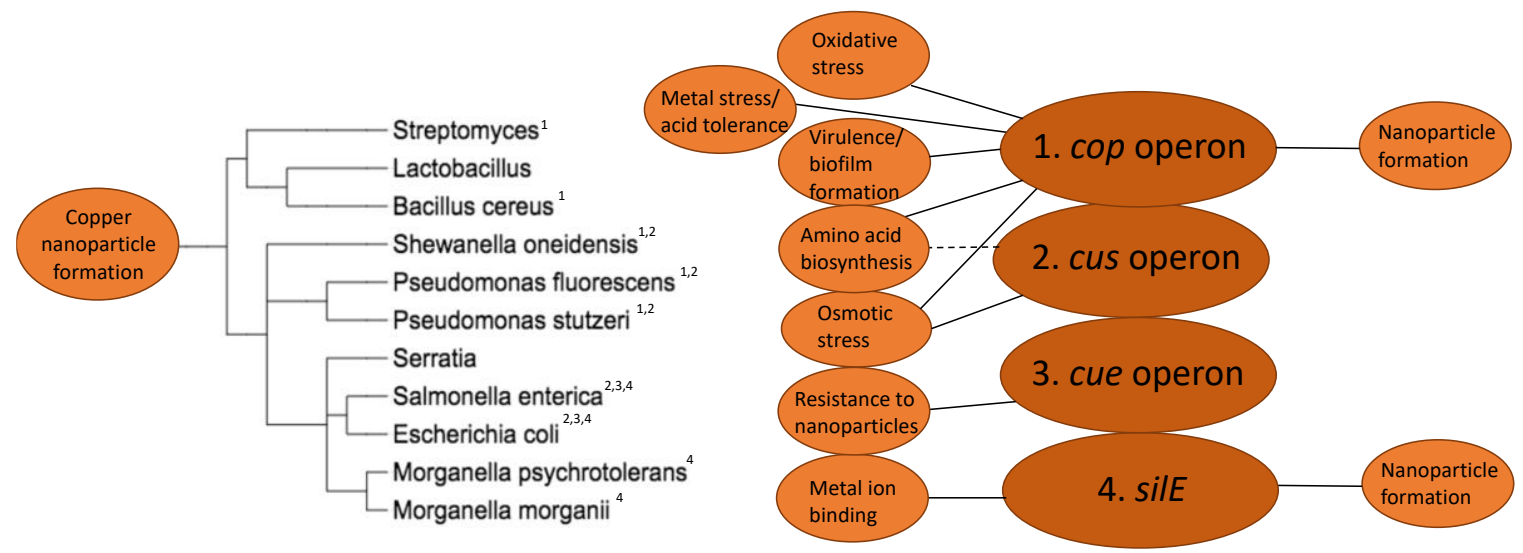

Fig. 7. Phylogenetic tree of some of the bacteria known to produce copper nanoparticles with numbers denoting the presence of specific copper resistance genes. Many of these genes also play roles in general stress responses to oxidative stress or acid stress.

\section{Concluding remarks}

Despite significant interest in nanoparticle biosynthesis by bacteria for a range of applications, this field remains limited by challenges due to a lack of understanding of the molecular mechanisms. Efforts have been made to connect nanoparticle biosynthesis to biological functions through generic enzymes such as reductases, but the connection between nanoparticle synthesis and the biological response to metal stress is still relatively unexplored. We have presented several examples for silver, gold, and copper, in which metal stress responses, nanoparticle biosynthesis, and general stress responses or metabolic processes are intertwined. It is interesting to note the reoccurring appearance of these resistance genes under stress conditions pertaining to oxidative stress, acid stress, osmotic stress, or metal stress, suggesting overlap between general and metal-specific stress responses. Many of these conditions are highly relevant to potential industrial applications for biosynthetic nanoparticles so it is critical to understand how these responses are associated in bacteria. In particular, the increasing use of metals and metallic nanoparticles as potential antibiotics and the observed links between metal resistance and pathogenicity are of significant concern. Additionally, as seen with gold and silver, it is possible for nonessential metals to commandeer existing metal resistance machinery to facilitate detoxification. It is probable that this occurs for other useful metals such as platinum and palladium, which are even less-studied. Ultimately, a greater understanding of how metal resistance machinery influences nanoparticle biosynthesis will illuminate the greater role of metal reduction and nanoparticle biosynthesis in bacteria and how it can be controlled on a systems-biology level. 


\section{ACKNOWLEDGMENTS}

A.C was supported by a National Science Foundation Graduate Research Fellowship (DGE1610403). This work was supported by the CINVESTAV/ConTex collaborative research grant (UTA17-001095) and the Defense Threat Reduction Agency Young Investigator Program (HDTRA1-17-1-0025).

\section{CONFLICT OF INTEREST}

The authors have no conflict of interest.

\section{REFERENCES}

Altimira F, Yáñez C, Bravo G, González M, Rojas LA, Seeger M. 2012. Characterization of copper-resistant bacteria and bacterial communities from copper-polluted agricultural soils of central Chile. BMC Microbiology 12:193.

Alqahtani M, Ketkar H, Suresh RV, Malik M, Bakshi CS. 2018. Characterization of a Unique Outer Membrane Protein Required for Oxidative Stress Resistance and Virulence of Francisella tularensis. Journal of Bacteriology 200:e00693-17.

Asiani KR, Williams H, Bird L, Jenner M, Searle MS, Hobman JL, Scott DJ, Soultanas P. 2016. SilE is an intrinsically disordered periplasmic " molecular sponge " involved in bacterial silver resistance. Molecular Microbiology 101:731-742.

Blakemore R. 1975. Magnetotactic Bacteria. Science 190:377-379.

Bogdan JA, Nazario-Larrieu J, Sarwar J, Alexander P, Blake MS. 2001. Bordetella pertussis Autoregulates Pertussis Toxin Production through the Metabolism of Cysteine. Infection and Immunity 69:6823-6830.

Bondarczuk K, Piotrowska-Seget Z. 2013. Molecular basis of active copper resistance mechanisms in Gram-negative bacteria. Cell Biology and Toxicology 29:397-405.

Brayner R, Barberousse H, Hemadi M, Djedjat C, Yéprémian C, Coradin T, Livage J, Fiévet F, Couté A. 2007. Cyanobacteria as Bioreactors for the Synthesis of Au, Ag, Pd, and Pt Nanoparticles via an Enzyme-Mediated Route. Journal of Nanoscience and Nanotechnology 7:2696-2708.

Butof L, Wiesemann N, Herzberg M, Altzschner M, Holleitner A, Reith F, Nies DH. 2018. Synergistic gold-copper detoxification at the core of gold biomineralisation in Cupriavidus. Metallomics 10:278-286.

Cantu-Bustos JE, Vargas-Cortez T, Morones-Ramirez JR, Balderas-Renteria I, Galbraith DW, Mcevoy MM, Zarate X. 2016. Expression and purification of recombinant proteins in 
Escherichia coli tagged with the metal-binding protein CusF. Protein Expression and Purification 121:61-65.

Carmel-Harel O, Storz G. 2000. Roles of the Glutathione - and Thioredoxin-Dependent Reduction Systems in the Escherichia coli and Saccharomyces cerevisiae Responses to Oxidative Stress. Annual Review of Microbiology 54:439-461.

Cerminati S, Giri GF, Mendoza JI, Soncini FC, Checa SK. 2017. The CpxR / CpxA system contributes to Salmonella gold-resistance by controlling the GolS-dependent gesABC transcription. Environmental Microbiology 19:4035-4044.

Checa SK, Soncini FC. 2011. Bacterial gold sensing and resistance. Biometals 24:419-427.

Chiang SM, Schellhorn HE. 2012. Regulators of oxidative stress response genes in Escherichia coli and their functional conservation in bacteria. Archives of Biochemistry and Biophysics 525:161-169.

Daniel M, Astruc D. 2004. Gold Nanoparticles: Assembly, Supramolecular Chemistry, Quantum-Size-Related Properties, and Applications toward Biology, Catalysis, and Nanotechnology. Chemical Reviews 104:293-346.

Das S, Dash HR, Chakraborty J. 2016. Genetic basis and importance of metal resistant genes in bacteria for bioremediation of contaminated environments with toxic metal pollutants. Applied Microbiology and Biotechnology 100:2967-2984.

De Windt W, Aelterman P, Verstraete W. 2005. Bioreductive deposition of palladium (0) nanoparticles on Shewanella oneidensis with catalytic activity towards reductive dechlorination of polychlorinated biphenyls. Environmental Microbiology 7:314-325.

Derakhshan FK, Dehnad A, Salouti M. 2012. Extracellular Biosynthesis of Gold Nanoparticles by Metal Resistance Bacteria : Streptomyces griseus. Synthesis and Reactivity in Inorganic, Metal-Organic, and Nano-Metal Chemistry 42:868-871.

Dixit R, Wasiullah, Malaviya D, Pandiyan K, Singh UB, Sahu A, Shukla R, Singh BP, Rai JP, Sharma PK, Lade H, Paul D. 2015. Bioremediation of Heavy Metals from Soil and Aquatic Environment: An Overview of Principles and Criteria of Fundamental Processes. Sustainability 7:2189-2212.

Djoko KY, Phan M, Peters KM, Walker MJ, Schembri MA, McEwan AG. 2017. Interplay between tolerance mechanisms to copper and acid stress in Escherichia coli. PNAS 114:6818-6823.

Durán M, Silveira CP, Durán N. 2015. Catalytic role of traditional enzymes for biosynthesis of biogenic metallic nanoparticles : a mini-review. IET Nanobiotechnology 9:314-323. 
Durán N, Seabra AB. 2012. Metallic oxide nanoparticles: state of the art in biogenic syntheses and their mechanisms. Applied Microbiology and Biotechnology 95:275-288.

Farmer KL, Thomas MS. 2004. Isolation and Characterization of Burkholderia cenocepacia Mutants Deficient in Pyochelin Production: Pyochelin Biosynthesis Is Sensitive to Sulfur Availability. Journal of Bacteriology 186:270-277.

Fayaz AM, Balaji K, Girilal M, Yadav R, Kalaichelvan PT, Venketesan R. 2010. Biogenic synthesis of silver nanoparticles and their synergistic effect with antibiotics: a study against gram-positive and gram-negative bacteria. Nanomedicine: Nanotechnology, Biology, and Medicine 6:103-109.

Festa RA, Thiele DJ. 2012. Copper at the Front Line of the Host-Pathogen Battle. PLOS Pathogens 8:e1002887.

Finley PJ, Norton R, Austin C, Mitchell A, Zank S, Durham P. 2015. Unprecedented Silver Resistance in Clinically Isolated Enterobacteriaceae: Major Implications for Burn and Wound Management. Antimicrobial Agents and Chemotherapy 59:4734-4741.

Fung DKC, Lau WY, Chan WT, Yan A. 2013. Copper Efflux Is Induced during Anaerobic Amino Acid Limitation in Escherichia coli To Protect Iron-Sulfur Cluster Enzymes and Biogenesis. Journal of Bacteriology 195:4556-4568.

Gadd GM. 2010. Metals, minerals and microbes: geomicrobiology and bioremediation. Microbiology 156:609-643.

Gholami-Shabani M, Shams-Ghahfarokhi M, Gholami-Shabani Z, Akbarzadeh A, Riazi G, Ajdari S, Amani A, Razzaghi-Abyaneh M. 2015. Enzymatic synthesis of gold nanoparticles using sulfite reductase purified from Escherichia coli: A green eco-friendly approach. Process Biochemistry 50:1076-1085.

Ghosh P, Han G, De M, Kim CK, Rotello VM. 2008. Gold nanoparticles in delivery applications. Advanced Drug Delivery Reviews 60:1307-1315.

González PJ, Correia C, Moura I, Brondino CD, Moura JJG. 2006. Bacterial nitrate reductases: Molecular and biological aspects of nitrate reduction. Journal of Inorganic Biochemistry 100:1015-1023.

Grass G, Rensing C, Solioz M. 2011. Metallic Copper as an Antimicrobial Surface. Applied and Enviromental Microbiology 77:1541-1547.

Grudniak AM, Kurek A, Szarlak J, Wolska KI. 2011. Oleanolic and Ursolic Acids Influence Affect the Expression of the Cysteine Regulon and the Stress Response in Escherichia coli. Current Microbiology 62:1331-1336. 
Gudipaty SA, McEvoy MM. 2014. The histidine kinase CusS senses silver ions through direct binding by its sensor domain. Biochimica et Biophysica Acta 1844:1656-1661.

Guo J, Gao S, Lu J, Bond PL, Verstraete W, Yuan Z. 2017. Copper Oxide Nanoparticles Induce Lysogenic Bacteriophage and Metal-Resistance Genes in Pseudomonas aeruginosa PAO1. ACS Applied Materials and Interfaces 9:22298-22307.

Gupta A, Matsui K, Lo J-F, Silver S. 1999. Molecular basis for resistance to silver cations in Salmonella. Nature Medicine 5:183-188.

Gupta S, Singh SP, Singh R. 2015. Synergistic Effect of Reductase and Keratinase for Facile Synthesis of Protein-Coated Gold Nanoparticles. Journal of Microbiology and Biotechnology 25:612-619.

Gurunathan S, Kalishwaralal K, Vaidyanathan R, Venkataraman D, Pandian SRK, Muniyandi J, Hariharan N, Eom SH. 2009. Biosynthesis, purification and characterization of silver nanoparticles using Escherichia coli. Colloids and Surfaces B: Biointerfaces 74:32835 .

Huang J, Li Q, Sun D, Lu Y, Su Y, Yang X, Wang H, Wang Y, Shao W, He N, Hong J, Chen C. 2007. Biosynthesis of silver and gold nanoparticles by novel sundried Cinnamomum camphora leaf. Nanotechnology 18:105104.

Hulkoti NI, Taranath TC. 2014. Biosynthesis of nanoparticles using microbes-A review. Colloids and Surfaces B: Biointerfaces 121:474-483.

Iravani S, Korbekandi H, Mirmohammadi SV, Zolfaghari B. 2014. Synthesis of silver nanoparticles: chemical, physical and biological methods. Research in Pharmaceutical Sciences 9:385-406.

Jiang W, Hou Y, Inouye M. 1997. CspA, the Major Cold-shock Protein of Escherichia coli, Is an RNA Chaperone*. The Journal of Biological Chemistry 272:196-202.

Johnson MDL, Kehl-fie TE, Klein R, Kelly J, Burnham C, Mann B, Rosch JW. 2015. Role of Copper Efflux in Pneumococcal Pathogenesis and Resistance to Macrophage-Mediated Immune Clearance. Infection and Immunity 83:1684-1694.

Karpinski P, Grudniak A, Wolska K. 2002. Effect of Mutations in dnaK and dnaJ Genes on Cysteine Operon Expression in Escherichia coli. Folia Microbiologica 47:371-374.

Kershaw CJ, Brown NL, Constantinidou C, Patel MD, Hobman JL. 2005. The expression profile of Escherichia coli K-12 in response to minimal, optimal and excess copper concentrations. Microbiology 151:1187-1198.

Khan SA, Ahmad A. 2014. Enzyme mediated synthesis of water-dispersible, naturally protein capped, monodispersed gold nanoparticles; their characterization and mechanistic aspects. RSC Advances 4:7729-7734. 
Knapp CW, Mccluskey SM, Singh BK, Campbell CD, Hudson G, Graham DW. 2011. Antibiotic Resistance Gene Abundances Correlate with Metal and Geochemical Conditions in Archived Scottish Soils. PLoS One 6:e27300.

Krulwich TA, Sachs G, Padan E. 2011. Molecular aspects of bacterial pH sensing and homeostasis. Nature Reviews Microbiology 9:330-343.

Kumar SA, Abyaneh MK, Gosavi SW, Kulkarni SK, Pasricha R, Ahmad A, Khan MI. 2007. Nitrate reductase-mediated synthesis of silver nanoparticles from $\mathrm{AgNO}_{3}$. Biotechnology Letters 29:439-445.

Li J, Pan Y. 2012. Environmental Factors Affect Magnetite Magnetosome Synthesis in Magnetospirillum magneticum AMB-1: Implications for Biologically Controlled Mineralization. Geomicrobiology Journal 29:362-373.

Li L, Xia Y, Zhang T. 2017. Co-occurrence of antibiotic and metal resistance genes revealed in complete genome collection. The ISME Journal 11:651-662.

Lin IW, Lok C, Che C. 2014. Biosynthesis of silver nanoparticles from silver(I) reduction by the periplasmic nitrate reductase c- type cytochrome subunit NapC in a silver-resistant $E$. coli. Chemical Science 5:3144-3150.

Lohße A, Borg S, Raschdorf O, Kolinko I, Tompa É, Pósfai M, Faivre D, Baumgartner J, Schüler D. 2014. Genetic Dissection of the mamAB and mms6 Operons Reveals a Gene Set Essential for Magnetosome Biogenesis in Magnetospirillum gryphiswaldense. Journal of Bacteriology 196:2658-2669.

Lok C, Ho C, Chen R, Tam PK, Chiu J, Che C. 2008. Proteomic Identification of the Cus System as a Major Determinant of Constitutive Escherichia coli Silver Resistance of Chromosomal Origin. Journal of Proteome Research 7:2351-2356.

Lund P, Tramonti A, Biase D De. 2014. Coping with low $\mathrm{pH}$ : molecular strategies in neutralophilic bacteria. FEMS Microbiology Reviews 38:1091-1125.

Lushchak VI. 2014. Free radicals, reactive oxygen species, oxidative stress and its classification. Chemico-Biological Interactions 224:164-175.

Magnani D, Solioz M. 2005. Copper chaperone cycling and degradation in the regulation of the cop operon of Enterococcus hirae. BioMetals 18:407-412.

Mewada A, Oza G, Pandey S, Sharon M. 2012. Extracellular Synthesis of Gold Nanoparticles Using Pseudomonas denitrificans and Comprehending its Stability. Journal of Microbiology and Biotechnology Research 2:493-499. 
Mittal AK, Chisti Y, Banerjee UC. 2013. Synthesis of metallic nanoparticles using plant extracts. Biotechnology Advances 31:346-356.

Moore JD, Avellan A, Noack CW, Guo Y, Lowry GV, Gregory KB. 2017. Time-dependent bacterial transcriptional response to $\mathrm{CuO}$ nanoparticles differs from that of $\mathrm{Cu}^{2+}$ and provides insights into $\mathrm{CuO}$ nanoparticle toxicity mechanisms. Environmental Science Nano 4:23212335.

Mu AL, Kjeldsen KU, Rattei T, Pester M, Loy A. 2015. Phylogenetic and environmental diversity of DsrAB-type dissimilatory ( bi ) sulfite reductases. The ISME Journal 9:11521165.

Mubarakali D, Thajuddin N, Jeganathan K, Gunasekaran M. 2011. Plant extract mediated synthesis of silver and gold nanoparticles and its antibacterial activity against clinically isolated pathogens. Colloids and Surfaces B: Biointerfaces 85:360-365.

Pankhurst QA, Connolly J, Jones SK, Dobson J. 2003. Applications of magnetic nanoparticles in biomedicine. Journal of Physics D: Applied Physics 36:R167-R181.

Parikh RY, Singh S, Prasad BLV, Patole MS, Sastry M, Shouche YS. 2008. Extracellular Synthesis of Crystalline Silver Nanoparticles and Molecular Evidence of Silver Resistance from Morganella sp.: Towards Understanding Biochemical Synthesis Mechanism. ChemBioChem 9:1415-1422.

Parikh RY, Ramanathan R, Coloe PJ, Bhargava SK, Patole MS, Shouche YS, Bansal V. 2011. Genus-Wide Physicochemical Evidence of Extracellular Crystalline Silver Nanoparticles Biosynthesis by Morganella spp. PLoS One 6:e21401.

Parsell DA, Taulien J, Lindquist S. 1993. The role of heat-shock proteins in thermotolerance. Philosophical Transactions: Biological Sciences 339:279-286.

Plewniak RIC, Koechler S, Navet B, Dugat-Bony E, Bouchez O, Peyret P, Seby F, BattagliaBrunet F, Bertin PN. 2013. Metagenomic insights into microbial metabolism affecting arsenic dispersion in Mediterranean marine sediments. Molecular Ecology 22:4870-4883.

Poock SR, Leach ER, Moir JWB, Cole JA, Richardson DJ. 2002. Respiratory Detoxification of Nitric Oxide by the Cytochrome c Nitrite Reductase of Escherichia coli *. The Journal of Biological Chemistry 277:23664-23669.

Porcheron G, Garénaux A, Proulx J, Sabri M, Dozois CM. 2013. Iron , copper, zinc , and manganese transport and regulation in pathogenic Enterobacteria: correlations between strains, site of infection and the relative importance of the different metal transport systems for virulence. Frontiers in Cellular and Infection Microbiology 3:1-24.

Prabhu S, Poulose EK. 2012. Silver nanoparticles : mechanism of antimicrobial action , 
synthesis, medical applications, and toxicity effects. International Nano Letters 2:32.

Prakash D, Gabani P, Chandel AK, Ronen Z, Singh OV. 2013. Bioremediation : a genuine technology to remediate radionuclides from the environment. Microbial Biotechnology 6:349-360.

Prasad R, Pandey R, Barman I. 2016. Engineering tailored nanoparticles with microbes : quo vadis? WIREs Nanomedicine and Nanobiotechnology 8:316-330.

Pugin B, Cornejo FA, Muñoz-Díaz P, Muñoz-Villagrán CM, Vargas-Pérez JI, Arenas FA, Vásquez CC. 2014. Glutathione Reductase-Mediated Synthesis of Tellurium-Containing Nanostructures Exhibiting Antibacterial Properties. Applied and Enviromental Microbiology 80:7061-7070.

Radtsig MA, Koksharova OA, Nadtochenko VA, Khmel IA. 2016. Production of Gold Nanoparticles by Biogenesis Using Bacteria. Microbiology 85:63-70.

Ramanathan R, Field MR, O'Mullane AP, Smooker PM, Bhargava SK, Bansal V. 2013. Aqueous phase synthesis of copper nanoparticles : a link between heavy metal resistance and nanoparticle synthesis ability in bacterial systems $\uparrow$. Nanoscale 5:2300-2306.

Randall CP, Gupta A, Jackson N, Busse D, O’Neill AJ. 2015. Silver resistance in Gramnegative bacteria: a dissection of endogenous and exogenous mechanisms. Journal of Antimicrobial Chemotherapy 70:1037-1046.

Reith F, Etschmann B, Grosse C, Moors H, Benotmane MA, Monsieurs P, Grass G, Doonan C, Vogt S, Lai B, Martinez-Criado G, George GN, Nies DH, Mergeay M, Pring A, Southam G, Brugger J. 2009. Mechanisms of gold biomineralization in the bacterium Cupriavidus metallidurans. PNAS 106:17757-17762.

Rensing C, Grass G. 2003. Escherichia coli mechanisms of copper homeostasis in a changing environment. FEMS Microbiology Reviews 27:197-213.

Riddin TL, Gericke M, Whiteley CG. 2006. Analysis of the inter- and extracellular formation of platinum nanoparticles by Fusarium oxysporum f. sp. lycopersici using response surface methodology. Nanotechnology 17:3482-3489.

Rubilar O, Rai M, Tortella G, Diez MC, Seabra AB, Durán N. 2013. Biogenic nanoparticles: Copper, copper oxides, copper sulphides, complex copper nanostructures and their applications. Biotechnology Letters 35:1365-1375.

Samanovic MI, Ding C, Thiele DJ, Darwin KH. 2012. Copper in Microbial Pathogenesis : Meddling with the Metal. Cell Host \& Microbe 11:106-115.

Schröfel A, Kratošová G, Šafarik I, Šafarikova M, Raška I, Shor LM. 2014. Applications of 
biosynthesized metallic nanoparticles - A review. Acta Biomaterialia 10:4023-4042.

Scott D, Toney M, Muzikar M. 2008. Harnessing the Mechanism of Glutathione Reductase for Synthesis of Active Site Bound Metallic Nanoparticles and Electrical Connection to Electrodes. Journal of the American Chemical Society 130:865-874.

Sekowska A, Kung HF, Danchin A. 2000. Sulfur Metabolism in Escherichia coli and Related Bacteria : Facts and Fiction. Journal of Molecular Microbiology and Biotechnology 2:145177.

Shahverdi AR, Minaeian S, Reza H, Jamalifar H, Nohi AA. 2007. Rapid synthesis of silver nanoparticles using culture supernatants of Enterobacteria: A novel biological approach. Process Biochemistry 42:919-923.

Singh K, Senadheera DB, Lévesque CM, Cvitkovitch DG. 2015. The copYAZ Operon Functions in Copper Efflux, Biofilm Formation, Genetic Transformation, and Stress Tolerance in Streptococcus mutans. Journal of Bacteriology 197:2545-2557.

Shivaji S, Prakash JSS. 2010. How do bacteria sense and respond to low temperature? Archives of Microbiology 192:85-95.

Silver S. 2003. Bacterial silver resistance : molecular biology and uses and misuses of silver compounds. FEMS Microbiology Reviews 27:341-353.

Solioz M, Stoyanov JV. 2003. Copper homeostasis in Enterococcus hirae. FEMS Microbiology Reviews 27:183-195.

Storz G, Imlay JA. 1999. Oxidative stress. Current Opinion in Microbiology 2:188-194.

Stoyanov JV, Brown NL. 2003. The Escherichia coli Copper-responsive copA Promoter Is Activated by Gold*. The Journal of Biological Chemistry 278:1407-1411.

Tan MP, Sequeira P, Lin WW, Phong WY, Cliff P, Ng SH, Lee BH, Camacho L, Schnappinger D, Ehrt S, Dick T, Pethe K, Alonso S. 2010. Nitrate Respiration Protects Hypoxic Mycobacterium tuberculosis Against Acid- and Reactive Nitrogen Species Stresses. PLoS One 5:e13356.

Tiwari M, Jain P, Chandrashekhar R, Narayanan K, K. UB, Udupa N, Rao VJ. 2016. Biosynthesis of copper nanoparticles using copper-resistant Bacillus cereus, a soil isolate. Process Biochemistry 51:1348-1356.

Xiao M, Zhu X, Fan F, Xu H, Tang J, Qin Y, Ma Y, Zhang X. 2017. Osmotolerance in Escherichia coli Is Improved by Activation of Copper Efflux Genes or Supplementation with Sulfur- Containing Amino Acids. Applied and Enviromental Microbiology 83:e03050-16. 
Yazdankhah S, Rudi K, Bernhoft A. 2014. Zinc and copper in animal feed - development of resistance and co-resistance to antimicrobial agents in bacteria of animal origin. Microbial Ecology in Health and Disease 25:25862.

Zammit CM, Weiland F, Brugger J, Wade B, Winderbaum LJ, Nies DH, Southam G, Hoffmann P, Reith F. 2016. Proteomic responses to gold(III)-toxicity in the bacterium Cupriavidus metallidurans CH34. Metallomics 8:1204-1216.

Zeller T, Klug G. 2006. Thioredoxins in bacteria : functions in oxidative stress response and regulation of thioredoxin genes. Naturwissenschaften 93:259-266.

Zhao Z, Zhou Z, Li L, Xian X, Ke X, Chen M, Zhang Y. 2014. A copper-responsive gene cluster is required for copper homeostasis and contributes to oxidative resistance in Deinococcus radiodurans R1. Molecular BioSystems 10:2607-2616. 